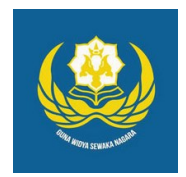

Jurnal Analogi Hukum

Journal Homepage: https://ejournal.warmadewa.ac.id/index.php/analogihukum

\title{
Pertimbangan Hakim dalam Putusan Perceraian yang Mengandung Unsur Tindak Pidana
}

\section{(Study Putusan No. 152/Pdt.G/2018/Pn.Dps)}

\author{
I Putu Bayu Permana*, A.A. Sagung Laksmi Dewi dan Diah Gayatri Sudibya \\ Universitas Warmadewa, Denpasar-Bali, Indonesia \\ *putubayu@gmail.com
}

How To Cite:

Permana, I, P, B., Dewi, A, A, S, L., Sudibya, D, G.(2020). Pertimbangan Hakim dalam Putusan Perceraian yang Mengandung Unsur Tindak Pidana (Study Putusan No. 152/Pdt.G/2018/Pn.Dps). Jurnal Analogi Hukum. 2 (3). 299-303. Doi: https://doi.org/10.22225/ah.2.3.2497.299-303

\begin{abstract}
The problem in this study is how the judges' consideration in the divorce decision contains elements of crime No. 152 / Pdt. G/20018 / Pn.Dps. where in developing countries Indonesia is very vulnerable to divorce. This is due to the fact that there are movie players or celebrities who divorce and remarry. In the making of the film also did the scene of remarrying without the knowledge of the first wife, which according to the author caused the divorce to be susceptible to an element of crime. Law No. 1 of 1974 concerning marriage has detailed explained the importance of marriage and the requirement to remarry, the formulation of the problem raised is how is the regulation of divorce containing criminal elements? And judges' consideration in deciding divorce cases that has elements of criminal offense? the issues that will be discussed later will be reviewed based on a normative point of view, the laws and regulations of Denpasar court No. 152 / Pdt. G / 20018 / Pn.Dps. Consider this judge in the decision no. 152 / Pdt. G / 20018 / Pn.Dps, considering that the plaintiff committed a criminal offense under article 279 KHUPidana, that it was the plaintiff who first made the attack arising from remarriage without the knowledge of the first wife, based on the Supreme Court jurisprudence No. 2571 k / Pdt / 1988 husbands or wives or parties that cause disputes and disputes, are not entitled or unable to act as plaintiffs. In the plaintiff's claim, the judge stated that the claim could not be accepted, and paid all court fees in the trial.
\end{abstract}

Keywords: Marriage; Divorce; Elements of criminal acts; Judge Considerations

\begin{abstract}
Abstrak-Permasalahan dalam penelitian ini bagaimana pertimbangan hakim dalam putusan perceraian yang mengandung unsur tindak pidana No.152/Pdt. G/20018/Pn.Dps. dimana di Negara berkembang Indonesia sangatlah rentan perceraian itu terjadi. Ini terjadinya di karena faktor adanya pemain film atau selebriti yang melakukan cerai dan menikah kembali. Di dalam pembuatan film juga melakukan adegan yang menikah kembali tanpa sepengetahuan istri pertama, ini yang menurut penulis sangat menyebabkan rentan terjadi perceraian terdapat unsur tindak pidana. Undang-undang no 1 tahun 1974 tentang perkawin sudah secara rinci menjelaskan pentingnya perkawinan dan syarat untuk menikah kembali, rumusan masalah yang di angkat adalah bagaimana pengaturan tentang perceraian yang mengandung unsur pidana? Dan pertimbangan hakim dalam memutus perkara perceraian yang terdapat unsur tindak pidana? Permasalahan yang akan di bahas nantinya akan dikaji berdasarkan sudut pandang normatif, perundangan-undangan dan putusan pengadilan denpasar No. 152/Pdt. G/20018/Pn.Dps. Pertimbangan hakim ini dalam putusan No. 152/Pdt. G/20018/ Pn.Dps ,menimbang bahwa penggugat melakukan tindak pidana dengan pasal 279 KUHPidana, bahwa penggugat lah yang pertama kali membuat percecokan itu timbul karena melakukan nikah kembali tanpa sepengetahuan istri pertama, berdasarkan yurisprudensi Mahkamah Agung No. $2571 \mathrm{k} / \mathrm{Pdt} / 1988$ suami atau istri atau pihak yang menjadi penyebab timbulnya perselisihan dan pertengkaran, tidak berhak atau tidak dapat bertindak sebagai penggugat. Dalam gugatanya penggugat, hakim menyatakan gugatan tidak dapat di terima, dan membayar seluruh biaya perkara dalam persidangan
\end{abstract}

Kata Kunci: Perkawinan; Perceraian; Unsur tindak pidana; Pertimbangan Hakim 


\section{Pendahuluan}

Setiap perkawinan tidak hanya didasarkan kepada kebutuhan biologis antara pria dan wanita yang diakui sah, melainkan sebagai pelaksana proses kodrat hidup manusia (Santoso, 2016). Perkawinan mempunyai tujuan membangun keluarga yang bahagia tidak telrepas dari lingkungan dan budaya di dalam membina dan menjaga hubungan suami istri. Apabila suatu perkawinan tidak dibarengi dengan suatu kesatuan tujuan, hal tersebut mengakibatkan terjadinya hambatan didalam mengarungi kehidupan keluarga, dan pada akhirnya terjadi suatu perselisihan dan perpecahan hubungan suami istri.

Permasalahan kehidupan rumah tangga semakin marak terjadi sekarang ini, yang disebabkan banyaknya permasalahan kebutuhan rumahtangga dan juga kemajuan pengethauan dan teknologi. Adanya tuntutan tersebut sehngga setiap rumah tangga berusaha untuk memenuhi kebutuhan-kebutuhan tersebut. Namun apabila kebutuhan tersbeut tidak terpenuhi maka muncullah permasalahan yang mengarah pada perceraian apabila hal tersebut tidak ditangani dengan baik oleh pasangan suami istri. Adanya kemajuan teknologi merupakan salah satu faktor yang mempengaruhi perceraian pasangan suami istri.

Perceraian pada hakekatnya adalah suatu proses dimana hubungan suami isteri tidak ditemukannya lagi keharmonisan dalam perkawinan (Zulkifli, 2019). Undang-undang perkawinan tidak mengatur dengan jelas tentang pengertian dari perceraian tersebut. Namun hanya menentukan bahwa perceraian meruapakn salah satu penyebab putusnya perkawinan. Sebab yang lain disebutkan antara lain kematian dan adnaya putusan dari pengadilan. Soebakti mendefinisikan perceraian adalah penghapusan perkawinan karena keputusan hakim atau tuntutan salah satu pihak dalam perkawinan (Soebekti, 1987).

Dari uraian dia tas dapat dikatakan bahwa undang-undang yang mengatur perkawinan pada hakekatnya memperketat celah untuk terjadinya perkawinan, undang-undang menentukan perceraian bisa dilakuan hanya di hadapan sidang pengadilan yang harus disertai dengan alasan-alasan yang cukup untuk dapat dilakukan perceraian. Penyebab putusnya suatu perkawinan adalah adanya talak atau juga berdasarkan gugatan perceraian.

Perkawinan jika tidak mendapatkan keharmonisan dan ketenangan akan menyebabkan timbulnya permasalahan dan tidak diridhakan Tuhan, dapat dipahami bahwa pernikahan harus berakhir, tetapi perceraian tidak dianggap mudah, karena perceraian tidak memungkinkan pernikahan terjadi jika di dalamnya terus terjadi pertengkaranpertengkaran dan masalah-masalah yang sepele.

Perceraian hanya diizinkan apabila terjadi permasalahan kompleks atau prinsip dalam rumah tangga. Selain itu, perceraian sejati diizinkan menurut Islam, tetapi di sisi lain, pernikahan diorientasikan pada komtimen yang kuat. Ketika ada perselisihan antara pihak suami dan istri, Islam tidak segera mendorong suami-istri untuk menyelesaikan pernikahan, namun didahului dengan perundingan. Perceraian hanya bisa dilaksanakan di sidang Pengadilan setelah Pengadilan yang bersangkutan berupaya dan gagal merekonsiliasi kedua pihak. Apabila pasangan suami istri ingin mengajukan perceraian harus didahulu dengan alasan yang kuat, bahwa antara suami dan istri tidak akan bisa hidup harmonis menjalani hubungan suami-istri. Dalam kasus perceraian, seorang ibu lebih sulit menjalani kehidupan untuk membesarkan anakanaknya sedangkan ayah kesulitannya untuk memikirkan bagaimana mengatasi kesulitan dalam situasi seperti ini. Apabila terjadi kasus perceraian, seorang ayah atau ibu memiliki cara yang berbeda dalam merawat dan memebsarkan anak-anaknya, seperti halnya perhatian yang diberikan keapda anak, keramahan dan pemberian kebebasan bagi anak-anak sangat berbeda. Hal ini dipengaruhi dengan kedekatan seorang ibu dengan anak-anaknya, sehingga dalam setiap kasus perceraian, seorang ibu dibebani dengan hak merawat anak-anaknya. Dalam kasus perceraian, apabila seorang ibu membesarkan seorang diri anaknya, otomatis cara mendidik anak menjadi lebih keras dan kurang menunjukkan kasih sayang kepada anak (Save M. Dagun, 1990 : 118).

Berdasarkan uraian latar belakang, dapat dirumuskan permasalahan sebagai berikut: Bagaimanakah pengajuan tentang gugatan perceraian yang mengandung unsur tindak pidana? Bagaimana Pertimbangan Hakim Dalam menyelesaikan Perkara perceraian, yang mengandung unsur tindak pidana?

\section{Metode}

Tipe penelitian dalam penelitian ini mengguankan tipe penelitian hukum normatif, yaitu dengan mengkaji peraturan perudnangundangan yang berlaku. Sumber bahan hukum dalam penelitian ini adalah sumber bahan hukum primer dan sekunder. Teknik pengumpulan bahan hukum menggunakan 
teknik studi pencatatan dan studi dokumentasi. Bahan hukum yang sudah terkumpul kemudian dianalisis dengan menggunakan argumentasi hukum yang didasakran atas logika hukum deduktif.

\section{Hasil Penelitian Dan Pembahasan}

\section{Pengaturan Hukum Tentang Pengajuan Gugatan Perkara Perceraian Yang Mengandung Unsur Tindak Pidana}

Perkataan cerai di dalam kamus berarti pisah, putusnya hubungan sebagai suami istri atau dapat juga dikatakan putuskan ikatan suatu perkawinan. Tetapi menurut peraturan yang berlaku, cerai harus didasarkan pada peraturan yang berlaku. Suatu perkawinan yang terjadi harus melalui prosedur yang ditentukan oleh hukum yaitu harus melalui lembaga peradilan. Lembaga peradilan yang berwenang adalah pengadilan agama untuk pasangan suami istri yang beragama islam dan untuk pasangan selain yang beragama islam melalui pengadilan negeri (Bahari, 2016).

Hukum perceraian dimana didalamnya terdapat unsur tindak pidana ini, di dalam perkara No. 152/Pdt.g/2018/Pn.Dps, suatu perkara perceraian yang terdapat unsur tindak pidana, dalam putusan ini adalah seorang suami telah menikah kembali tanpa diketahui oleh sang istri, dimana di dalamnya terdapat unsur pidana. Dan sang istri telah melaporkan suami kepada kepolisian Republik Indonesia Resta Denpasar.

Pengaturan tentang Perceraian terdapat Unsur Tindak Pidana dalam peraturan perundangan yang berlaku antara lain

Salah satu pihak yang melakukan perzinahan atau menjadi pemabuk, pemadat, penjudi dan sebagainya sulit disembuhkan.

Salah seorang dari pasangan meninggalkan pasangannya lebih dari 2 tahun secara berturutturut tanpa adanya alasan yang sah atau ada alsan lain terlepas dari kemampuannya

Salah satu pihak dihukum penjara selama Lima tahun ataupun hukuman yang lebih besar setelah tejradi pernikahan.

Salah satu pihak melakukan kekejaman dan penganiayaan terhadap pihak lainnya dan membahayakan pihak lainnya

Salah satu pihak terkena cacat atau sakit dan tidak mampu melaksankaan kewajiban sebagai suami istri.
Terjadinya

perseliaihna

ndan pertengkaran yang terus menerus antara suami dan istri dan sulit untuk hidup harmonis

Didalam menangani kasus perceraian Perkara No. 152/Pdt.g/2018/Pn. DPs hakim menggunakan peraturan perundangundangan yang berlaku sesuai dengan putusan pengadilan negeri denpasar.

\section{Pertimbangan Hakim dalam Memutus Perkara Perceraian yang Terdapat Tindak Pidana}

Hakim meurpakan pejabat pengadilan negara yang berwenang untuk mengadili menurut undang-undang yang berlaku.

Di dalam kehidupan masyarakat sekarang ini, hakim menurut peraturan yang berlaku mempunyai kedudukan sebagai lembaga yang menyelesaikan seitap permasalahan yang timbul. Untuk itu, seorang hakim dalam melakukan tugasnya tidak diperbolehkan memihak pada salah satu pihak selain berpihak pada kebenaran dan pada keadilan serta pada nilai-nilai kemanusiaan (Barda Nawawi Arief : 2).

Demi terwujudnya nilai putusan hakim yang adil dan mengandung kepastian hukum, maka pertimbangan suatu hakim sangat penting. Selain itu pertimbangan hakim dapat memberikan manfaat bagi kedua belah pihak yang berperkara, sehingga dalam memberikan pertimbangan, hakim harus bersikap teliti, baik dan cermat. Sehingga tidak dibatalkan oleh pengadilan tinggi/ mahmakah agung (Arto, 2004).

Seorang hakim di dalam melaksanakan pemeriskaan perkara diperlukan suatu pembuktian. Karena di dalam memutusa suatu perkara diperlukan adnaya pembuktian. Pembuktian adalah proses yang terpenting di dalam pemeriskaan di persidangan. Tujuan dilakukan pembuktian adalah untuk mempeorleh kepastian bahwa peristiwa yang diajukan memang benar terjadi sehingga memperoleh putusan hakim yang benar dan adil.

Hakim tidak dapat menjatuhkan suatu putusan sebelum nyata baginya bahwa peristiwa/ fakta tersebut benar-benar terjadi, yakni di buktikan kebenaranya, sehingga Nampak adanya hubungan hukum antara para pihak (Arto, 2004). 


\begin{abstract}
Kekuasaan kehakiman adalah
kekuasaan yang bersifat merdeka yang berarti kekuasana hakim bebas dari campur tangan pihak kekausaan ekstra yudisial, terkecuali hal-hal yang disebutkan di dalam peraturan perundangan yang berlaku.
\end{abstract}

Kebebasan dalam melakasanakan wewenang yudisial bersifat tidak mutlak karena tugas hakim adalah menegakan hukum dan keadilan berdasarkan pancasila, sehingga putusanya mencerminkan rasa keadilan rakyat Indonesia.

Di dalam melaksanakna tugas sebagai seorang hakim, maka dalam melakukan penegakan hukum hakim tidak bersikap memikah. Di dalam memberikan suatu keadilan hakim harus memilah kebenaran suatu peristiwa yang diajukan di depan hakim untuk selanjutnya diberi penilaian terhadap peristiwa atau kejadian tersebut kemduian mengaitkan dengan peraturan perundangan yang berlaku.

Setelah memastikan bahwa peristiwa itu benar-benar terjadi, maka hakim baru bisa memberikan putusan. Seorang hakim tidak boleh menolak memeriksa dan mengadili suatu peristiwa yang dilimpahkan kepadanya karena seorang hakim dianggap tahu mengeai hukumnya.

Seorang hakim dalam menemukan hukumnya diizinkan untuk merefleksikan yurisprudensi dan pendapat para ahli hukum terkenal (Doktrin). Ketika seorang hakim menjatuhkan vonis tidak sematamata tidak hanya didasarkan pada normanorma hukum yang berlaku di masyarakat.

Seorang hakim di dalam memutuskan suatu putusan didasari peraturan yang berlaku, meskipun demikian hakim tidak hanya mengacu pada peraturan yang bersifat teoritis, namun harus mengacu perihal nyata liannya dalam perkara tersbeut yang tentunya tidak sama satu sama lainnya

Hakim dalam memutus perkara pada dasarnya mengacu pada peraturan perundangan yang berlaku di negara kita, namun demikian Hakim tidak hanya mempertimbangkan masalah peraturan yang sifatnya teoretis semata melainkan juga mempertimbangkan hal-hal konkret lainnya yang ada di setiap perkara, yang tentunya tidak sama satu dengan yang lainnya. Dalam penulisan hukum ini, penulis melakukan penelitian tentang perceraian dengan nomor perkara: 152/ Pdt.G/2018/PN Dps.

Setelah melakukan pertimbangan tersbut, kemudian hakim melakukan perundingan dan musyawarah hingga akhirnya Hakim mengeluarkan Putusan Nomor :152/Pdt.G/2018/PN Dps, yang pada amar putusannya berbunyi:

Menyatakan gugatan Penggugat tidak dapat diterima;

Menghukum $\begin{gathered}\text { Penggugat untuk } \\ \text { membayar biaya perkara, sebesar }\end{gathered}$
Rp.476.000,- (Empat Ratus Tujuh Puluh
Enama Ribu Rupiah)

Dalam praktik peradilan dalam keputusan hakim sebelum pertimbangan peradilan terbukti. Kemudian hakim akan menarik fakta-fakta dalam persidangan yang muncul dan merupakan kesimpulan kumulatif dari pernyataan kepada saksi, kesaksian terdakwa dan bukti. Pertimbangan hakim terdiri dari dua bagian, yaitu pertimbangan yuridis dan non-yuridis. Pertimbangan yuridis merpakan penilaian hakim berdasarkan fakta-fakta yuridis yang diungkapkan di depan sidang pengadilan dan oleh Hukum yang ditetapkan sebagaimana harus dimasukkan dalam putusan seperti dakwaan jaksa penuntut umum, pernyataan terdakwa, pernyataan saksi, bukti, dan pasal dalam hukum pidana peraturan. Sedangkan pertimbangan nonyuridis dapat dilihat dari latar belakang terdakwa, kondisi terdakwa dan agama terdakwa (Muhammad, 2007).

Dengan adanya prinsip hukum, maka bisa melahirkan peraturan hukum. Dan prinsip hukum tidak akan habis setelah membentuk peraturan hukum, prinsip hukum dapat terus melahirkan peraturan hukum lainnya. Satjipto Rahardjo mengatakan dalam bukunya bahwa prinsip hukum mengandung nilai dan tuntutan etika. Maka prinsip hukum adalah perantara antara peraturan hukum dan cita-cita sosial dan pandangan etis dari masyarakat. sehingga, prinsip hukum membuat 
perundangan berubah karakter sebagai tatanan etis (Rahardjo, 2004).

Untuk memahami aturan hukum, ia harus terlebih dahulu memahami prinsip hukumnya. Dalam mencari makna dan tujuan dalam peraturan hukum, orang biasa melakukan penarikan peraturan hukum dari pemahaman tingkat awal ke pemahaman tingkat yang lebih tinggi atau yang biasa disebut rasio legis.

Dengan menerapkan rasio legislatif, kita juga dapat menemukan arahan etis dari peraturan yang ada. Makna yang telah ditarik pada tingkat yang lebih tinggi juga dapat ditarik pada tingkat yang lebih tinggi dan terus menerus sampai suatu penemuan segera, yang berarti tidak dapat dijelaskan pada tingkat yang lebih tinggi.

\section{Simpulan}

Pengaturan hukum tentang pengajuan kasus perceraian yang mengandung unsurunsur pelanggaran pidana, di mana peraturan tentang perceraian yang mengandung unsur-unsur pidana diatur dalam pasal 279 ayat (1) KUHP berbunyi.

"Barang siapa mengadakan perkawainan padahal mengetahui bahwa perkawinan atau perkawinan-perkawinanya yang telah ada menjadi pnghalang yang sah untuk itu di ancaman dengan pidana penjara paling lama Lima tahun”.

Unsur-unsur yang terkandung dalam pasal 279, yang merupakan unsur barang siapa dan melakukan perkawinan ketika mengetahui bahwa pernikahan mereka yang ada adalah penghalang yang sah bagi mereka

Pertimbangan hakim dalam memutus perkara dengan nomer: 152/Pdt.g/2018/Pn. Dps. Menimbang bahwa sesuai yurisprudensi Mahkamah Agung No. 2571 $\mathrm{K} / \mathrm{Pdt} / 1988$, suami atau istri atau pihak yang menjadi penyebab timblnya perselisihanya dan pertengkaran, tidak berhak atau tidak dapat bertindak sebagai Penggugat menuntut perceraian berdasarkan pasal 19 huruf (f) P.P. No. 9 tahun 1975, sehingga Penggugat tidak dapat mengajukan gugatan Aquo, Menimbang bahwa berdasarkan pertimbangan tersebut diatas, maka Gugatan Penggugat dinyatakan tidak dapat diterima dan menghukum penggugat untuk membayar biaya perkara, sebesar Rp.476.000,(Empat Ratus Tujuh Puluh Enama Ribu Rupiah).

\section{Daftar Bacaan}

Arto, M. (2004). Praktek Perkara Perdata pada Pengadilan Agama. Yogyakarta: Pustaka Pelajar.

Bahari, A. (2016). Tata cara gugatan cerai pembagian harta gono-gini dan hak asuh anak. Pustaka Yustisia.

Muhammad, R. (2007). Hukum Acara Pidana Kontemporer. Bandung: PT Citra Aditya Bakti.

Rahardjo, S. (2004). Ilmu Hukum; Pencarian, Pembebasan dan Pencerahan. Surakarta: Muhammadiyah Press University.

Santoso. (2016). Hakekat Perkawinan Menurut Undang-Undang Perkawinan, Hukum Islam Dan Hukum Adat. Yudisia, 7(2). Retrieved from https:// journal.iainkudus.ac.id/index.php/ Yudisia/article/download/2162/1790

Soebekti. (1987). Pokok-Pokok Hukum Perdata. PT Inter Massa.

Zulkifli, S. (2019). Putusnya Perkawinan Akibat Suami Menikah Tanpa Izin Dari Istri. JURNAL HUKUM KAIDAH Media Komunikasi Dan Informasi Hukum Dan Masyarakat, 18(3). Retrieved from https://jurnal.uisu.ac.id/ index.php/jhk/article/ download/1184/942 